\title{
Consumer Trust in Food and the Food System: A Critical Review
}

\author{
Wen Wu ${ }^{1, *}$, Airong Zhang ${ }^{2} \mathbb{D}$, Rieks Dekker van Klinken ${ }^{2} \mathbb{D}$, Peggy Schrobback ${ }^{3}$ and Jane Marie Muller $^{2}$ \\ 1 Data61, The Commonwealth Scientific and Industrial Research Organisation (CSIRO), \\ Brisbane 4102, Australia \\ 2 Health and Biosecurity, The Commonwealth Scientific and Industrial Research Organisation (CSIRO), \\ Brisbane 4102, Australia; airong.zhang@csiro.au (A.Z.); rieks.vanklinken@csiro.au (R.D.v.K.); \\ jane.muller@csiro.au (J.M.M.) \\ 3 Agriculture and Food, The Commonwealth Scientific and Industrial Research Organisation (CSIRO), \\ Brisbane 4067, Australia; peggy.schrobback@csiro.au \\ * Correspondence: drwenwu.uq@gmail.com
}

Citation: Wu, W.; Zhang, A.; van Klinken, R.D.; Schrobback, P.; Muller, J.M. Consumer Trust in Food and the Food System: A Critical Review. Foods 2021, 10, 2490. https:/ / doi.org/10.3390/foods10102490

Academic Editor: Pascal Schlich

Received: 14 September 2021

Accepted: 14 October 2021

Published: 18 October 2021

Publisher's Note: MDPI stays neutral with regard to jurisdictional claims in published maps and institutional affiliations.

Copyright: (c) 2021 by the authors. Licensee MDPI, Basel, Switzerland. This article is an open access article distributed under the terms and conditions of the Creative Commons Attribution (CC BY) license (https:// creativecommons.org/licenses/by/ $4.0 /)$.

\begin{abstract}
Increased focus towards food safety and quality is reshaping food purchasing decisions around the world. Although some food attributes are visible, many of the attributes that consumers seek and are willing to pay a price premium for are not. Consequently, consumers rely on trusted cues and information to help them verify the food quality and credence attributes they seek. In this study, we synthesise the findings from previous research to generate a framework illustrating the key trust influencing factors that are beyond visual and brand-related cues. Our framework identifies that consumer trust in food and the food system is established through the assurances related to individual food products and the actors of the food system. Specifically, product assurance builds consumer trust through food packaging labels communicating food attribute claims, certifications, country or region of origin, and food traceability information. In addition, producers, processors, and retailers provide consumers with food safety and quality assurances, while government agencies, third-party institutions, advocacy groups, and the mass media may modify how labelling information and food operators are perceived by consumers. We hope our framework will guide future research efforts to test these trust factors in various consumer and market settings.
\end{abstract}

Keywords: assurance; food actor; packaging label; traceability; supply chain operator; food industry influencer

\section{Introduction}

The globalisation of food supply chains and the increasing complexity of modern food systems are changing the relationship consumers have with food. Enhanced focus towards food safety and quality has reshaped the way contemporary consumers evaluate food and make purchase decisions. Specifically, several serious food safety incidents, cases of food fraud, and changes in food production practices have violated consumer trust across the globe [1-5]. While not all of these incidents have directly imposed risks to public health and safety, they do represent a breach of consumer trust and have reduced consumer confidence in the integrity of the food system [1,2,6-9].

As food supply chains become increasingly globalised, there is a need to understand the range of cues and information that consumers trust and rely on when navigating the complexities of the modern food system. Consumers with high levels of trust have confidence in the quality of the food items they are purchasing, and that the food operators who produce, distribute, and sell food are meeting relevant standards [10]. Food quality refers to the tangible sensory characteristics of food, such as taste, flavour, freshness, juiciness, and appearance [11]. Food quality can also incorporate less tangible credence attributes including nutritional value, functional quality, and convenience aspect of food, 
as well as ethical and environmental considerations. In some instances, food quality represents prestige, and an individual's social status and wealth $[12,13]$ Food safety can also be considered as an attribute of food quality, and it refers to the safe handling and storing of food $[14,15]$. Safe foods are free from harmful biological, chemical, or physical agents.

Growth in income and awareness of the health, social, and environmental consequences of food choices has increased global demand for diverse, safe, and premium foods with specific attributes (e.g., organic, eco-friendly, nutritious) [16-20]. Consumers commonly use direct visual and physical cues related to individual food items (e.g., colour, firmness, size, and price) when assessing food quality. For example, consumers from Asia tend to assess meat quality based on the colour of the meat and its level of intramuscular fat $[21,22]$. However, there are a growing number of credence attributes that consumers consider in their purchasing decisions that cannot be directly inferred through search or experience, such as safety, nutrition, environmental protection, and animal welfare. Traditionally, branding, marketing, and advertising have been used to communicate such credence attributes of certain food items and influence consumer choice [23,24]. Over the past decades, however, the growing complexity and globalised scale of the food system have presented increased opportunities for fraud and food safety incidents to occur [25,26]. Consequently, consumers must rely on additional cues and information to help them assess the full suite of credence attributes they seek [16]. Thus, the scope of this review is focused towards outlining the cues and information beyond product branding and marketing that consumers trust for verifying the less visible food attributes.

Extensive research has examined various factors that influence consumer trust, including trust in supply chain actors, assurance and regulatory systems, and the economic development status of the producing country $[14,16,17,27-30]$. While these efforts have advanced our understanding of consumer trust, much of the previous studies have focused on particular aspects of trust in food and the food system, with some findings being country and culture specific [31,32]. As a result, the factors influencing consumer trust identified in the literature are often fragmented, and at times, contradictory.

In this study, we critically review the literature to generate a framework showing the diverse range of factors that influence consumer trust in food and the food system. We use this framework and review to discuss the trust-influencing factors that are well-supported by previous research, as well as areas that future research could further explore.

\section{Materials and Methods}

Given the vast amount of existing research examining consumer trust, we aim to critically synthesise the main themes discussed in the literature and construct a framework outlining the key factors influencing consumer trust (Figure 1).

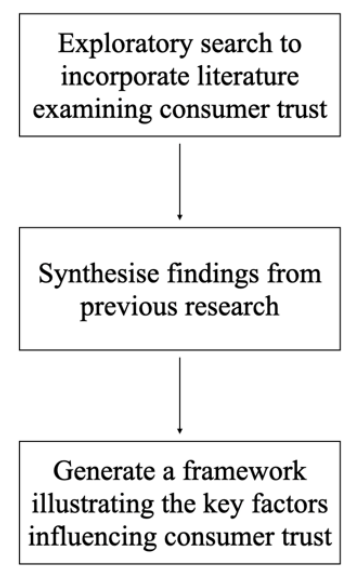

Figure 1. A flowchart illustrating the methodology steps. 
An exploratory search was conducted to incorporate literature examining trust indicators used by consumers, food-related attributes that attract a price premium, consumer trust in the food supply chain, consumer trust in product credentials and verification systems, and consumer use of food verification information. The selection criteria for studies to be considered in our review include that the study is written in English, the study is published in a peer-reviewed journal, and the study is published between 2000 and 2021.

For the literature search, we used search terms related to 'consumer trust', 'purchasing behaviour', and 'trusted food indicators' to explore the key attributes that consumers look for and rely on when purchasing food items to ensure that the food is safe and of high quality. Search terms related to 'willingness to pay' for food with added attributes were included as well. In addition, 'trust in food certification', 'trust in food traceability systems', and 'valued information used to verify food credentials' were used to evaluate what information consumers rely on when verifying food attributes. Lastly, terms related to 'trust in the food supply chain' were used to support the analysis of consumer trust in supply chain actors. The search terms were applied as keywords in the titles, abstracts, and body of the journal articles in academic databases, including Emerald Insights, PLoS ONE, MDPI, Wiley Online Library, Springer Link, ProQuest, Taylor and Francis Online, Oxford Academic, and ScienceDirect.

Our search identified 133 relevant articles examining factors influencing consumer trust in food and the food system. Of the reviewed journal articles, approximately 40 percent evaluated trust in domestic foods, 40 percent examined both domestic and imported foods, and 10 percent assessed imported foods only. Food categories investigated in these studies included liquid milk, infant milk powder, eggs, cheese, meats, organic food, fruit, vegetables, rice, cooking oil, Fairtrade products, and sustainable foods. Because this review aims to summarise the range of factors shaping consumer trust, we took the consumer perspective and only included articles that investigated cues and information that are visible to the consumer.

\section{Results and Discussion}

We developed a framework that summarises the range of diverse trust-influencing factors reported in the literature that help consumers verify the less visible food attributes they seek (Figure 2). Our first step was to list all the factors, identified from our review, that influence consumer trust in food and the food system. We then grouped the different factors according to how they are perceived by the consumer and incorporated them into the framework.

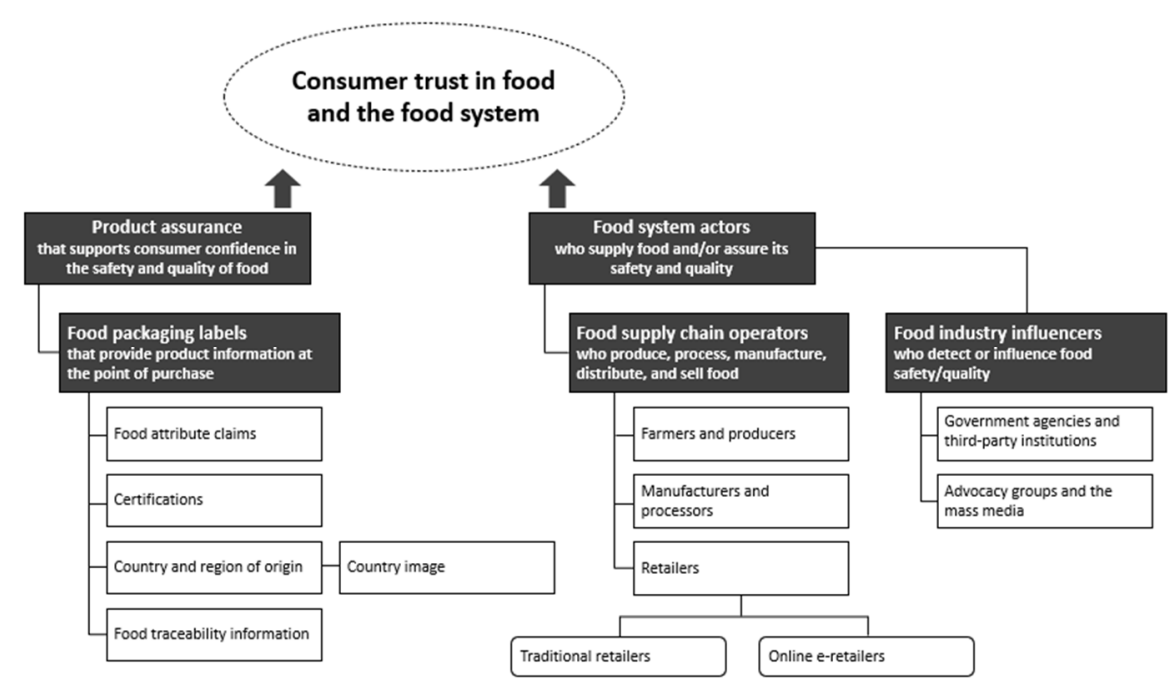

Figure 2. A framework summarising the range of factors that influence consumer trust in food and the food system. 
Our review showed that the identified factors influence consumer trust in two distinct ways: either at the product level through labelling, or indirectly through actors of the food system. Providing direct assurance on the safety and quality of food items through food attribute claims, certifications, country and region of origin, and food traceability information, builds consumer confidence and trust. Because these factors related to product assurance are mainly made accessible to consumers through printed labels on food packaging, they were summarised in the framework as factors related to food packaging labels that consumers trust. Our description of food packaging labels also incorporates product related information that appear on information boards in physical retail stores, especially for nonpacked foods, or on a webpage of an online retail store. In addition, we found two separate groups of food system actors who play a role in influencing consumer trust. While consumers trust producers, processors, and retailers for supplying high quality foods, government agencies, third-party institutions, advocacy groups, and the mass media are positioned to modify how labelling information and food operators are assessed by consumers.

We present the key factors related to product assurance and food system actors that influence consumer trust. Differences in findings are also discussed from the perspectives of culture and economic development.

\subsection{Product Assurance}

Product assurance aims to enhance consumer confidence in food and demonstrate that it is authentic and meets relevant industry standards for safety and quality. Because food items are often accompanied with printed labels that describe various credence attributes that consumers are seeking, food packaging labels are the primary tangible cues that consumers have access to and use at the time of purchase to validate product attributes and assurance claims (Figure 2).

\section{Food Packaging Labels}

Product labelling is the written information on the packaging of a food product that informs consumers about its unique attributes, quality certifications, country of origin, and production region. It also enables access to food traceability information. Labelling information, and links to traceability information, can also be presented on information boards in physical retail stores, as well as appear on a webpage when consumers are shopping online. Labels act as a direct communication channel from producers, retailers, regulators, and third-party certifiers to consumers [33]. They can also display branding and marketing information, food safety and quality information, as well as information including ingredients, instruction, and uses. Food packaging labels, therefore, are positioned at the interface between consumers, food, and the food system. From our analysis of the various factors influencing consumer trust, we consider food packaging labels that communicate food attribute claims, certifications, country and region of origin, and food traceability information to be the most tangible information sources that consumers can rely on for identifying and validating the different credence attributes they seek.

Food attribute claims. Food attribute claims mostly include quality related characteristics that cannot be visually or physically examined by the consumer at the time of purchase. These quality characteristics include, for example, taste, ingredients, and production methods. Ethical and environmental considerations, as well as the nutritional value, functional quality, and convenience aspects of food, among others, are also less tangible and require labelling for consumers to distinguish. While food attribute labels can include a variety of information and vary from product to product, research shows that consumers tend to prefer simple and clearly presented food attributes on packaging, such as 'free-from', ingredients, nutritional information, and expiry date [16,17,34-37]. For example, Australian consumers tend to look for simple labels describing the specific cut of meat to help assess its eating quality. Asian consumers, on the other hand, tend to value a variety of different 
labelling information, including country and region of origin, attributes associated with improved health, and the personal quality of producers [37].

Certifications. Food labels can also display certification information that supports specific credence claims that are otherwise un-observable, such as organic, Halal, freerange, animal welfare, environmental sustainability, or Fairtrade. Certification labels help consumers validate authenticity and support their confidence in food. Studies of certification labelling show that scientifically certified expert labels are the most trusted. A study of 10,000 consumers from Japan, the United States, Germany, China, and Thailand showed that consumers trusted certified labels endorsed by scientific experts more than those supported by producers, the government, and consumers [38]. Trust in scientific experts indicates the value of scientific testing for food quality and safety assurance.

Increased food scares and incidents across many developing countries have motivated consumers from these regions to trust international certifications more than domestic equivalents $[14,35,39-43]$. However, there is contradictory evidence suggesting that some consumers can be discouraged from purchasing internationally certified food products $[22,27,29,42,44,45]$. These findings could relate to consumers in developing countries being less familiar with international certification labels, or perceiving offshore certification as more costly than domestic certification $[22,27,29,42,44]$. Another variation to the general preference in developing countries for international certification is associated with the certification of foods related to a specific cultural domain, such as Halal. For example, Malaysian consumers tend to prefer and trust Halal certified food products from Muslim countries, such as Saudi Arabia, Pakistan or Brunei, over certifications from non-Muslim countries such as China, New Zealand, European countries, and Thailand [45].

Country and region of origin. Geographical labels are often used as an important differentiating tool for assessing food safety, quality, and authenticity [46]. Specifically, consumers use geographical labels as the main differentiation tool for high-value products, such as wine [46]. Moreover, geographical labels are sometimes presented alongside other attributes, such as eco labels, for consumers to develop brand associations [47]. The literature indicates that geographical labels are valued by all consumer segments regardless of culture $[21,37,48]$.

Country image. Globalisation of the food industry enables consumers to access a diverse range of foods from countries and regions around the world. Studies indicate that consumers often rely on their general perception, or the country image, of the producing country as an indication of food safety and quality $[49,50]$. The perceived 'image' or overall impression a consumer has about a country creates a 'halo effect' of positive or negative feelings towards products that are produced from that country or place [14,51-53].

In general, positive feelings about an exporting country being warm and friendly build trust $[49,54,55]$. Positive feelings derived from a perceived 'clean and green' image of an exporting country also play a role in influencing consumer trust. The degree to which a country is perceived to have a naturally beautiful and unspoiled environment has been shown to increase consumers' willingness to purchase imported foods from that country [49,56]. For example, consumers in France perceived eco-labelled products less favourably when associated with a country that tends to portray less of an eco-friendly image than when the same products were associated with a country perceived as environmentally friendly [57].

The economic development of a country, and its perceived competence, also act as an important cue for food safety and quality $[17,28,49]$. In general, food safety incidents across Asia have resulted in many consumers preferring imported foods from economically developed countries over domestic foods. For example, consumers in China rated genetically modified orange juice coming from Australia and the United States as higher quality than genetically modified juice from China, Brazil, and Israel [58]. Increased trust towards economically developed countries for producing genetically engineered foods seems to suggest an existing perception among consumers that these countries have better regula- 
tory systems in place, and are more advanced in implementing agricultural technologies and biotechnologies [58].

In contrast, European consumers prefer food products from countries that are geographically closer in distance $[29,59]$. Even in Albania and Kosovo where food safety incidents related to domestic production are prevalent, consumers still consider domestic food to be safer and of higher quality than imported foods [34]. A study of consumer preference for the origin of seafood in Europe showed consumers to value domestic, local, and European production over foreign imports [60]. In addition, consumers in Denmark consider geographical origin as more important than whether or not the food is organic or the size of the production company [61]. European consumers believe that locally produced foods are fresher, require less transport, and are better regulated than foreign foods [62]. They also value the economic benefits associated with purchasing locally produced foods [61]. Across other developed economies, similar domestic and local preference has been found among consumers in the United States and in Australia [63,64].

Food traceability information. Food traceability systems capture information related to the origin of food products and document their journey across the supply chain [3]. These systems play an important role in supporting food safety and quality by providing increased transparency across the food supply chain [65]. While food traceability has historically been used as a supply chain risk management tool by agribusinesses and retailers, it is increasingly applied to enhance consumer confidence in food authenticity, safety, and quality. Traceability data is made accessible to consumers through barcodes, Quick Response (QR) codes, radio-frequency identification, and online links printed on food packaging $[3,66,67]$. Supported by cloud computing, storage technologies, and more recently decentralised blockchain networks, food traceability information made available to consumers reduces information asymmetry and increases trust [3,68-70]. Food traceability systems offer consumers reassurances on the origin and history of food products, raise the standards of food safety and quality across the international markets, and help build consumer confidence and trust in the traced food products [71-74].

Traceability information that verifies where the food product was produced, and how it was processed and grown, reassures consumers about the food's authenticity, and provides substantial value in assisting the management of food incidents [8,75-83]. Across the developing countries, increased food safety instances and fraud have intensified consumer demand for detailed information about origin, manufacturing processes, and agricultural inputs [72,84-89]. Studies show that consumers from China, Vietnam, Malaysia, and Brazil value food traceability and are willing to pay a price premium for traced foods $[37,44,72,90-95]$.

However, in developed countries where there have been fewer food safety incidents, studies show consumers engage less with food traceability information. Interviews with the major Australian retailers revealed that time-poor consumers often have little interest in the mechanics of the food supply chain [68]. Others have found that, while Australian consumers put more emphasis on having imported food traced, their trust in the information provided by the traceability system of imported food products was low [96]. Thus, more work may be needed to establish strategies to increase consumer knowledge about food traceability systems across the globe and their engagement with the tracked data $[96,97]$.

While traceability systems designed to improve consumer confidence through increased transparency are promising, consumers trust in traceability systems and information is less clear. Emerging evidence suggests that traceability information that is validated by an independent party helps to build consumer trust. Through a discrete choice experiment with Fuji apple in China, Liu et al. (2020) found that the majority of Chinese consumers regarded traceability validation as far more important than the traceability itself. In addition, they placed the highest value on government validation and were willing to pay a price premium for apples validated by the government compared to those validated by domestic or international third-party certifiers. 


\subsection{Food System Actors}

While providing product assurance through food packaging labels directly supports consumer confidence in food products, food system actors also play an important role in influencing consumer confidence and trust in food and the food system. Food system actors are those who are directly involved in the production and distribution of food, including farmers and producers, manufactures and processors, and retailers. On a dayto-day basis, consumers have the greatest opportunity to develop face-to-face reciprocal relationships with retailers. Their engagement with the upstream food operators, such as producers and food companies, tends to be minimal. In the event of food incidents, however, upstream food actors often become more of a focus for consumers [88,98,99]. Food system actors also include industry influencers who assure or monitor food safety and quality, including government agencies and third-party institutions, consumer advocacy groups, and the mass media. Although industry influencers are not directly responsible for the production and distribution of food, they are positioned to influence how food is governed and certified, and can directly communicate with the public about food safety and quality. In the remaining of the Results and Discussions section, we outline the actors along the supply chain, including food industry influencers, to whom consumers trust and assign responsibility for ensuring food safety and quality.

\subsubsection{Food Supply Chain Operators}

Globalisation and the complexity of the food supply chain is increasing the physical distance between consumers and industry operators who produce, process, manufacture, distribute, and sell food $[25,100]$. Consequently, consumers often have limited knowledge about where their food has been grown and produced, and how it has been processed and distributed along the supply chain [98,101]. Research suggests that consumers tend to put more trust in the operators from the downstream parts of the food supply chain, such as retailers, than those from upstream [48].

Farmers and producers. Consumer trust in the supply chain operators who directly grow and produce food differs around the world. Consumers from countries that experience limited food safety scares and rely on local produce tend to put more trust in famers [98,102]. For example, Henderson et al. (2011) found that consumers in Australia display high levels of trust towards farmers. Similarly, consumers across Europe, especially those from France, Poland, and Italy, tend to base their purchasing decisions on the farmer who produced the food [31,103]. Consumers from developing countries, on the other hand, tend to trust farmers the least. For example, food scares and fraudulent practices across many cities of China have reduced trust among urban consumers in local farmers and producers [38,104]. However, consumers from rural China who are able to source food directly from farmers tend to put more trust in local farmers who also produce for their own consumption [27,32].

Manufactures and processors. In general, consumers' connection with and trust towards food manufactures and processors tends to be low [3,31]. During food safety incidents, consumers tend to direct the responsibility for re-building and maintaining trust towards these actors. An online survey of consumers in France, Germany, Poland, Spain, and the United Kingdom showed that trust is established by consumers' belief that supply chain actors, especially manufactures, are competent, caring, and open [31]. Consumer trust in domestic food manufactures tends to be low in China [42]. However, there are indications that the introduction of new food safety laws, following food product scandals, has improved some Chinese consumers' confidence and trust in manufactures for ensuring food safety and quality [105].

Retailers. As consumers become more disconnected from food supply chain operators, especially those from the upstream producers, processors, and manufactures, they increasingly rely on retailers to ensure food safety and quality. Both traditional and online retailers build trust through developing ongoing consumer-retailer relationships, ensuring all economic transactions are secure, and fostering positive consumer feedback [106-109]. Traditional retailers with a physical presence, such as supermarkets, grocery stores, butch- 
ers, and farmers' markets, build trust through direct consumer-retailer relationships and food networks [3]. Personal trust developed between the consumer and retailer acts as a cue for food quality and safety [34]. For example, consumers from Albania indicated that their main source of trust when evaluating food quality and safety is knowing the butcher or seller [110]. Across China, where food fraud and safety incidents are common, consumers reported the highest level of trust in large reputable international retailers selling imported foods from developed countries [27,32,104]. Despite a price premium on imported foods from reputable stores, these retailers are perceived to offer greater assurances on product authenticity and operate within the regulatory control of the government [37,111]. Chinese consumers tend to perceive smaller independent retailers and street vendors as more risky and likely to be involved in fraudulent practices [32].

Compared to traditional face-to-face retailers who physically operate in a commercial location, consumer trust in online e-retailers can be more fragile and difficult to establish [112]. E-retailers need to use more indirect approaches to build trust with their customers, such as the look of their website and online reviews. A study of Chinese consumers found organic food information presented on a media-rich website reduced perceived risk and improved trust in the retailer [113]. Another study of 420 mobile shopping app users in India showed that online trust can be highly influenced by the visual attractiveness of the mobile shopping app [114]. Innovative website features have also been shown to build trust towards online shopping sites and increase consumers' repurchasing intentions [109]. In particular, e-retailer sites with added human and social elements strengthened trust through providing consumers with an indirect sense of personalness and warmth [115-117]. Online reviews also enable consumers to indirectly access product quality and safety information through the lived experiences of other consumers [113]. Long reviews with more detailed information of a product are perceived as higher quality and more useful than simpler reviews [118]. In addition, positive or factual reviews, and reviews appearing on social networks, are often perceived as more trustworthy than negative or emotional reviews, and reviews appearing on retailer sites [118].

\subsubsection{Food Industry Influencers}

Food industry influencers are in a position to confirm or challenge the legitimacy of the food attribute claims made by food actors, and to shape consumers' perception of the risks related to food safety and quality. While government agencies and third-party institutions influence consumer trust through certification labelling that validates certain food attribute claims, consumer advocacy groups and the mass media influence trust through directly communicating with consumers about the trustworthiness of food operators. There are some minor cultural differences in who consumers trust for communicating the relevant information relating to food safety and quality.

Government agencies and third-party institutions. Government regulatory agencies and third-party institutions can enhance consumer confidence through providing independent validation and certification of the credence attributes claimed by food producers, processors, and manufactures. The validation provided by these influencers can be communicated to consumers through product labelling. As a consequence of increased food incidents across many developing countries, consumers from these regions trust government authorities and third-party institutions, over food supply chain operators, for ensuring the safety and quality of domestically produced food products $[111,119]$. For example, consumers in Taiwan display higher levels of trust and preference towards government-supported food inspections over those conducted by operators [119]. Chinese consumers hold high levels of trust towards independent institutions for providing quality and safety guarantees of domestically produced foods [105]. They generally perceive government and third-party institutions (e.g., research institutes and consumer associations) to be knowledgeable and accurate in their communication of food safety and quality information, and care about the health and wellbeing of the public [111,119]. 
Advocacy groups and the mass media. As consumer demand for ethical food production and consumption increases across the developed countries, advocacy groups who communicate directly with consumers about the trustworthiness of food operators for producing ethical foods are playing an increasing role in influencing consumer trust [120]. The mass media, in particular traditional news channels and social media, has been an important portal for advocacy groups to rapidly expose poor behind-the-scenes practices, food fraud, and food safety incidents $[32,111,119]$. Media representation can powerfully influence consumer perceptions of food-related issues, especially those with which the general public have limited direct experience [120]. For example, animal welfare activists exposed industry wrong doings within the live export industry through broadcasting video footage of animal mistreatment in the slaughterhouse of the importing countries, and poor welfare conditions within intensive piggeries and broiler sheds [120]. The widespread broadcast of these videos across the mass media led to the suspension of Australian cattle exports to countries exposed for mistreating animals and the closure of Australian operations with poor animal welfare. The work of advocacy groups has given rise to dramatic changes in consumer attitudes towards animal production and welfare [121]. Bray and Ankeny (2017) found that Australian consumers perceive free-range and cage-free eggs as better quality, more nutritious, safer, and tastier than caged eggs. These changes have accelerated consumer demand for ethical foods and have pushed many retailers across the developed countries to establish new animal welfare standards for producers [120].

\section{Conclusions}

Income growth, increased awareness of health benefits of foods, and ongoing food safety incidents are accelerating consumer demand for safe and quality foods that cannot easily be distinguished based on visual and physical cues. Although branding and marketing strategies are widely used to communicate the credence attributes of food products, the complex, fragmented, and globalised modern food system presents growing opportunities for food incidents, fraud, and poor practices to occur. Consequently, agribusinesses and supply chain stakeholders have taken various approaches to address consumer concerns and secure their confidence in food safety and quality.

The present review developed a food trust framework and revealed that consumer trust can be built through product assurance and food system actors. Our findings show that product assurance through food packaging labels that communicate food attributes, certifications, country or region of origin, and food traceability are one important set of tangible cues and sources of information that consumers trust when assessing food safety and quality at the time of purchase. In addition, food system actors, particularly retailers and food industry influencers, who detect or directly communicate with the public about food safety and quality, also play a crucial role in influencing consumer trust.

While there are similarities in the cues and information consumers trust and rely on for ensuring food safety and quality across the globe, the specific ways in which these factors operate can vary between countries and cultures. For example, geographical labels indicating the country and region from which the food was produced tend to be valued by all consumers. However, consumers from Europe tend to primarily rely on geographical origin for evaluating food safety and quality, while consumers in Asia tend to rely on more detailed labelling information that includes origin, but also health related attributes and personal qualities of producers.

Ongoing food safety incidents seem to have motivated consumers across developing countries to prefer imported foods and quality certifications from economically developed countries over domestic equivalents. Despite a price premium on foods, consumers from developing countries appear to trust reputable international retailers and manufactures over local producers. They tend to trust government authorities and third-party institutes for regulating and validating food safety and quality over advocacy groups and the mass media. In many of the developed countries, however, there is a general preference for domestic food products over foreign imports, even in countries where food safety incidents 
related to domestic production are prevalent. Consumers from developed countries with fewer experiences of food incidents tend to put more trust in local farmers and retailers who sell local produce than food manufactures. Compared to consumers from developing countries, the purchasing decisions of those from developed countries tend to be influenced more by the advocacy movements championing animal warfare and ethical consumption.

Our findings also suggest that consumers may have greater confidence in product assurance systems that are supported by the food system actors they trust. While food packaging labels help consumers validate credence attributes, food system actors provide consumers with an added layer of safety and quality assurance. To contrast consumers from developed countries, those from developing countries tend to trust government authorities and third-party institutions (e.g., research institutes and consumer associations) over food supply chain operators for validating food traceability information and ensuring the safety and quality of domestic food products. While digital and traceability systems present opportunities for food system actors to provide consumers with added transparency and assurance across the food supply chain, research investigating consumer trust in traceability information appears limited at present. Future research needs to establish a better understanding of what traceability information consumers value and the validation that they trust. It should also be noted that there appears to be a disconnect between what consumers state they trust under experimental settings and their actual purchase behaviour at the time of purchase [23]. Improved methods need to be developed that better capture actual consumer behaviour under experimental settings.

Overall, our framework offers the first step in understanding the key drivers of consumer trust and how those may be influenced by culture. While our framework highlights the individual importance of food packaging labels, supply chain actors, and industry influencers when evaluating consumer trust, more work is required to establish their relative importance. Knowing the relative importance of these main factors influencing consumer trust has implications for the design and further development of credentialing and traceability systems. We hope our framework will guide future research and food industry efforts to test these trust factors in various consumer and market settings, and develop systems and strategies for building and maintaining consumer trust.

Author Contributions: W.W.: Conceptualization, Formal analysis, Investigation, Writing-Original draft, Visualization, Project administration; A.Z.: Conceptualization, Validation, Writing-Review \& Editing; R.D.v.K.: Conceptualization, Validation, Writing-Review \& Editing; P.S.: Conceptualization, Validation, Writing—Review \& Editing, J.M.M.: Conceptualization, Validation, Writing-Review \& Editing. All authors have read and agreed to the published version of the manuscript.

Funding: This research was supported by the Commonwealth Scientific and Industrial Research Organisation as part of the Trusted Agrifood Exports Mission.

Institutional Review Board Statement: Not applicable.

Informed Consent Statement: Not applicable.

Data Availability Statement: Not applicable.

Acknowledgments: A special thanks to Ryan McAllister for contributing his valuable time and expertise in supporting the thinking behind this paper and proofreading the article.

Conflicts of Interest: The authors declare no conflict of interest. The funders had no role in the design of the study; in the collection, analyses, or interpretation of data; in the writing of the manuscript, or in the decision to publish the results.

\section{References}

1. Henderson, J.; Ward, P.R.; Coveney, J.; Meyer, S.B. What are the important issues around food safety and nutrition? Findings from a media analysis and qualitative study of consumer trust. Australas. Med. J. 2010, 3, 164-169. [CrossRef]

2. Esteki, M.; Regueiro, J.; Simal-Gándara, J. Tackling fraudsters with global strategies to expose fraud in the food chain. Compr. Rev. Food Sci. Food Saf. 2019, 18, 425-440. [CrossRef] 
3. Kendall, H.; Clark, B.; Rhymer, C.; Kuznesof, S.; Hajslova, J.; Tomaniova, M.; Brereton, P.; Frewer, L. A systematic review of consumer perceptions of food fraud and authenticity: A European perspective. Trends Food Sci. Technol. 2019, 94, 79-90. [CrossRef]

4. Agnoli, L.; Capitello, R.; De Salvo, M.; Longo, A.; Boeri, M. Food fraud and consumers' choices in the wake of the horsemeat scandal. Br. Food J. 2016, 118, 1898-1913. [CrossRef]

5. Thomson, B.; Poms, R.; Rose, M. Incidents and impacts of unwanted chemicals in food and feeds. Qual. Assur. Saf. Crop. Foods 2012, 4, 77-92. [CrossRef]

6. Zachmann, K.; Østby, P. Food, technology, and trust: An introduction. Hist. Technol. 2011, 27, 1-10. [CrossRef]

7. Tonkin, E.; Wilson, A.; Coveney, J.; Henderson, J.; Meyer, S.B.; McCarthy, M.B.; O’Reilly, S.; Calnan, M.; McGloin, A.; Kelly, E.; et al. Food-system actors' perspectives on trust: An international comparison. Br. Food J. 2019, 121, 561-573. [CrossRef]

8. Yamoah, F.; Yawon, D. Assessing supermarket food shopper reaction to horsemeat scandal in the UK. Int. Rev. Manag. Mark. 2014, 4, 98-107.

9. ABC News. Strawberry Needle Contamination Scare: Queensland Woman Charged after Months-long Investigation. 2018. Available online: https:/ / www.abc.net.au/news/2018-11-11/strawberry-needle-scare-woman-arrested-in-queensland/1048 6418 (accessed on 1 March 2021).

10. Bozic, B. Consumer trust repair: A critical literature review. Eur. Manag. J. 2017, 35, 538-547. [CrossRef]

11. Yu, H.; Neal, J.A.; Sirsat, S.A. Consumers' food safety risk perceptions and willingness to pay for fresh-cut produce with lower risk of foodborne illness. Food Control 2018, 86, 83-89. [CrossRef]

12. Nuttavuthisit, K.; Thøgersen, J. Developing-Economy preferences for imported organic food products. J. Int. Consum. Mark. 2019, 31, 225-249. [CrossRef]

13. Batra, R.; Ramaswamy, V.; Alden, D.; Steenkamp, J.B.E.M.; Ramachander, S. Effects of brand local and nonlocal origin on consumer attitudes in developing countries. J. Consum. Psychol. 2000, 9, 83-95. [CrossRef]

14. Manning, L.; Soon, J.M. Food Safety, Food Fraud, and Food Defense: A Fast Evolving Literature. J. Food Sci. 2016, 81, R823-R834. [CrossRef] [PubMed]

15. Röhr, A.; Lüddecke, K.; Drusch, S.; Müller, M.J.; Alvensleben, R.V. Food quality and safety-Consumer perception and public health concern. Food Control 2005, 16, 649-655. [CrossRef]

16. Yeh, C.-H.; Menozzi, D.; Török, Á. Eliciting egg consumer preferences for organic labels and omega 3 claims in Italy and Hungary. Foods 2020, 9, 1212. [CrossRef] [PubMed]

17. Thøgersen, J.; Pedersen, S.; Aschemann-Witzel, J. The impact of organic certification and country of origin on consumer food choice in developed and emerging economies. Food Qual. Prefer. 2019, 72, 10-30. [CrossRef]

18. Maehle, N.; Iversen, N.; Hem, L.; Otnes, C. Exploring consumer preferences for hedonic and utilitarian food attributes. Br. Food J. 2015, 117, 3039-3063. [CrossRef]

19. Van Rijswijk, W.; Frewer, L.J. Consumer perceptions of food quality and safety and their relation to traceability. Br. Food J. 2008, 110, 1034-1046. [CrossRef]

20. Zhang, A.; Jakku, E. Australian Consumers' Preferences for Food Attributes: A Latent Profile Analysis. Foods 2021, 10, 56. [CrossRef]

21. Hastie, M.; Ashman, H.; Torrico, D.; Ha, M.; Warner, R. A Mixed Method Approach for the Investigation of Consumer Responses to Sheepmeat and Beef. Foods 2020, 9, 126. [CrossRef]

22. Wu, L.; Wang, S.; Zhu, D.; Hu, W.; Wang, H. Chinese consumers' preferences and willingness to pay for traceable food quality and safety attributes: The case of pork. China Econ. Rev. 2015, 35, 121-136. [CrossRef]

23. Joshi, Y.; Rahman, Z. Factors Affecting Green Purchase Behaviour and Future Research Directions. Int. Strateg. Manag. Rev. 2015, 3, 128-143. [CrossRef]

24. Seo, S.S.; Kim, K.; Nurhidayati, V.A. Satisfaction and purchase intention of imported fresh fruits based on familiarity: A case of Korean pears in Taiwan. Br. Food J. 2020, 122, 2895-2910. [CrossRef]

25. Giampietri, E.; Verneau, F.; Giudice, T.D.; Carfora, V.; Finco, A. A Theory of Planned behaviour perspective for investigating the role of trust in consumer purchasing decision related to short food supply chains. Food Qual. Prefer. 2018, 64, 160-166. [CrossRef]

26. Kjærnes, U. Ethics and action: A relational perspective on consumer choice in the European politics of food. J. Agric. Environ. Ethics 2012, 25, 145-162. [CrossRef]

27. Kendall, H.; Kuznesof, S.; Dean, M.; Chan, M.Y.; Clark, B.; Home, R.; Stolz, H.; Zhong, Q.; Liu, C.; Brereton, P.; et al. Chinese consumer's attitudes, perceptions and behavioural responses towards food fraud. Food Control 2019, 95, 339-351. [CrossRef]

28. Schjøll, A. Country-of-origin preferences for organic food. Org. Agric. 2017, 7, 315-327. [CrossRef]

29. Ortega, D.L.; Hong, S.J.; Wang, H.H.; Wu, L. Emerging markets for imported beef in China: Results from a consumer choice experiment in Beijing. Meat Sci. 2016, 121,317-323. [CrossRef]

30. Mirosa, M.; Mangan-Walker, E. Young Chinese and functional foods for mobility health: Perceptions of importance, trust, and willingness to purchase and pay a premium. J. Food Prod. Mark. 2018, 24, 216-234. [CrossRef]

31. Macready, A.L.; Hieke, S.; Klimczuk-Kochańska, M.; Szumial, S.; Vranken, L.; Grunert, K.G. Consumer trust in the food value chain and its impact on consumer confidence: A model for assessing consumer trust and evidence from a 5-country study in Europe. Food Policy 2020, 92, 101880. [CrossRef]

32. Soon, J.M.; Liu, X. Chinese consumers' risk mitigating strategies against food fraud. Food Control 2020, 115, 107298. [CrossRef] 
33. Tonkin, E.; Webb, T.; Coveney, J.; Meyer, S.B.; Wilson, A.M. Consumer trust in the Australian food system-the everyday erosive impact of food labelling. Appetite 2016, 103, 118-127. [CrossRef]

34. Haas, R.; Imami, D.; Miftari, I.; Ymeri, P.; Grunert, K.; Meixner, O. Consumer Perception of Food Quality and Safety in Western Balkan Countries: Evidence from Albania and Kosovo. Foods 2021, 10, 160. [CrossRef]

35. Dang, A.K.; Tran, B.X.; Nguyen, C.T.; Le, H.T.; Do, H.T.; Nguyen, H.D.; Nguyen, L.H.; Nguyen, H.T.; Mai, H.T.; Tran, T.D.; et al. Consumer preference and attitude regarding online food products in Hanoi, Vietnam. Int. J. Environ. Res. Public Health 2018, 15, 981. [CrossRef] [PubMed]

36. Hartmann, C.; Hieke, S.; Taper, C.; Siegrist, M. European consumer healthiness evaluation of 'Free-from'labelled food products. Food Qual. Prefer. 2018, 68, 377-388. [CrossRef]

37. El Benni, N.; Stolz, H.; Home, R.; Kendall, H.; Kuznesof, S.; Clark, B.; Dean, M.; Brereton, P.; Frewer, L.J.; Chan, M.Y.; et al. Product attributes and consumer attitudes affecting the preferences for infant milk formula in China-A latent class approach. Food Qual. Prefer. 2019, 71, 25-33. [CrossRef]

38. Rupprecht, C.D.D.; Fujiyoshi, L.; McGreevy, S.R.; Tayasu, I. Trust me? Consumer trust in expert information on food product labels. Food Chem. Toxicol. 2020, 137, 111170. [CrossRef]

39. Wu, L.; Yin, S.; Xu, Y.; Zhu, D. Effectiveness of China's organic food certification policy: Consumer preferences for infant milk formula with different organic certification labels. Can. J. Agric. Econ. 2014, 62, 545-568. [CrossRef]

40. Yin, S.; Chen, M.; Xu, Y.; Chen, Y. Chinese consumers' willingness-to-pay for safety label on tomato: Evidence from choice experiments. China Agric. Econ. Rev. 2017, 141-155. [CrossRef]

41. Nuttavuthisit, K.; Thøgersen, J. The importance of consumer trust for the emergence of a market for green products: The case of organic food. J. Bus. Ethics 2017, 140, 323-337. [CrossRef]

42. Wang, J.; Tao, J.; Chu, M. Behind the label: Chinese consumers' trust in food certification and the effect of perceived quality on purchase intention. Food Control 2020, 108, 106825. [CrossRef]

43. Moruzzo, R.; Riccioli, F.; Boncinelli, F.; Zhang, Z.; Zhao, J.; Tang, Y.; Tinacci, L.; Massai, T.; Guidi, A. Urban Consumer Trust and Food Certifications in China. Foods 2020, 9, 1153. [CrossRef]

44. Liu, R.; Gao, Z.; Snell, H.A.; Ma, H. Food safety concerns and consumer preferences for food safety attributes: Evidence from China. Food Control 2020, 112, 107157. [CrossRef]

45. Rezai, G.; Mohamed, Z.; Shamsudin, M.N. Assessment of consumers' confidence on halal labelled manufactured food in Malaysia. Pertanika J. Soc. Sci. Humanit. 2012, 20, 33-42.

46. Santeramo, F.G.; Lamonaca, E. Evaluation of geographical label in consumers' decision-making process: A systematic review and meta-analysis. Food Res. Int. 2020, 131, 108995. [CrossRef] [PubMed]

47. Song, Y.; Qin, Z.; Yuan, Q. The impact of eco-label on the young Chinese generation: The mediation role of environmental awareness and product attributes in green purchase. Sustainability 2019, 11, 973. [CrossRef]

48. Van Wezemael, L.; Verbeke, W.; Kügler, J.O.; de Barcellos, M.D.; Grunert, K.G. European consumers and beef safety: Perceptions, expectations and uncertainty reduction strategies. Food Control 2010, 21, 835-844. [CrossRef]

49. Feng, N.; Zhang, A.; Van Klinken, R.D.; Cui, L. An integrative model to understand consumers' trust and willingness to buy imported fresh fruit in urban China. Br. Food J. 2021, 123, 2216-2234. [CrossRef]

50. Yeh, C.-H.; Chen, C.-I.; Sher, P.J. Investigation on perceived country image of imported food. Food Qual. Prefer. 2010, 21, 849-856. [CrossRef]

51. Andéhn, M.; Nordin, F.; Nilsson, M.E. Facets of country image and brand equity: Revisiting the role of product categories in country-of-origin effect research. J. Consum. Behav. 2016, 15, 225-238. [CrossRef]

52. Pedersen, S.; Aschemann-Witzel, J.; Thøgersen, J. Consumers' evaluation of imported organic food products: The role of geographical distance. Appetite 2018, 130, 134-145. [CrossRef]

53. Gorostidi-Martinez, H.; Xu, W.; Zhao, X. A review of Spanish consumers' product-country image of China. Asia Pac. J. Mark. Logist. 2017. [CrossRef]

54. Halkias, G.; Davvetas, V.; Diamantopoulos, A. The interplay between country stereotypes and perceived brand globalness/localness as drivers of brand preference. J. Bus. Res. 2016, 69, 3621-3628. [CrossRef]

55. Chen, C.Y.; Mathur, P.; Maheswaran, D. The effects of country-related affect on product evaluations. J. Consum. Res. 2014, 41, 1033-1046. [CrossRef]

56. Costa, C.; Carneiro, J.; Goldszmidt, R. A contingent approach to country-of-origin effects on foreign products evaluation: Interaction of facets of country image with product classes. Int. Bus. Rev. 2016, 25, 1066-1075. [CrossRef]

57. Dekhili, S.; Achabou, M.A. Towards greater understanding of ecolabel effects: The role of country of origin. J. Appl. Bus. Res. 2014, 30, 433-438. [CrossRef]

58. Gao, Z.; Yu, X.; Li, C.; McFadden, B.R. The interaction between country of origin and genetically modified orange juice in urban China. Food Qual. Prefer. 2019, 71, 475-484. [CrossRef]

59. McCarthy, B.L. Trends in organic and green food consumption in China: Opportunities and challenges for regional Australian exporters. J. Econ. Soc. Policy 2015, 17, 6.

60. Zander, K.; Feucht, Y. Consumers' willingness to pay for sustainable seafood made in Europe. J. Int. Food Agribus. Mark. 2018, 30, 251-275. [CrossRef] 
61. Denver, S.; Jensen, J.D.; Olsen, S.B.; Christensen, T. Consumer preferences for 'Localness' and organic food production. J. Food Prod. Mark. 2019, 25, 668-689. [CrossRef]

62. Meyerding, S.G.; Trajer, N.; Lehberger, M. What is local food? The case of consumer preferences for local food labeling of tomatoes in Germany. J. Clean. Prod. 2019, 207, 30-43. [CrossRef]

63. Ariyawardana, A.; Ganegodage, K.; Mortlock, M.Y. Consumers' trust in vegetable supply chain members and their behavioural responses: A study based in Queensland, Australia. Food Control 2017, 73, 193-201. [CrossRef]

64. Alfnes, F.; Sharma, A. Locally produced food in restaurants: Are the customers willing to pay a premium and why? Int. J. Revenue Manag. 2010, 4, 238-258. [CrossRef]

65. Behnke, K.; Janssen, M. Boundary conditions for traceability in food supply chains using blockchain technology. Int. J. Inf. Manag. 2020, 52, 101969. [CrossRef]

66. Daoud, M.K.; Trigui, I.T. Smart Packaging: Consumer's Perception and Diagnostic of Traceability Information. In International Conference on Digital Economy; Springer: Berlin/Heidelberg, Germany, 2019.

67. Cao, S.; Powell, W.; Foth, M.; Natanelov, V.; Miller, T.; Dulleck, U. Strengthening consumer trust in beef supply chain traceability with a blockchain-based human-machine reconcile mechanism. Comput. Electron. Agric. 2021, 180, 105886. [CrossRef]

68. Meat and Livestock Australia. Commercial Application of Supply Chain Integrity and Shelf Life Systems; Meat and Livestock Australia: Sydney, Australia, 2020.

69. Sander, F.; Semeijn, J.; Mahr, D. The acceptance of blockchain technology in meat traceability and transparency. Br. Food J. 2018. [CrossRef]

70. Bumblauskas, D.; Mann, A.; Dugan, B.; Rittmer, J. A blockchain use case in food distribution: Do you know where your food has been? Int. J. Inf. Manag. 2020, 52, 102008. [CrossRef]

71. Benson, T.; Benson, T.; Lavelle, F.; Spence, M.; Elliott, C.T.; Dean, M. The development and validation of a toolkit to measure consumer trust in food. Food Control 2020, 110, 106988. [CrossRef]

72. Liu, R.; Gao, Z.; Nayga Jr., R.M.; Snell, H.A.; Ma, H. Consumers' valuation for food traceability in China: Does trust matter? Food Policy 2019, 88, 101768. [CrossRef]

73. Menozzi, D.; Halawany-Darson, R.; Mora, C.; Giraud, G. Motives towards traceable food choice: A comparison between French and Italian consumers. Food Control 2015, 49, 40-48. [CrossRef]

74. Wu, L.; Wang, H.; Zhu, D.; Hu, W.; Wang, S. Chinese consumers' willingness to pay for pork traceability information-The case of Wuxi. Agric. Econ. 2016, 47, 71-79. [CrossRef]

75. Matzembacher, D.E.; Stangherlin, I.D.C.; Slongo, L.A.; Cataldi, R. An integration of traceability elements and their impact in consumer's trust. Food Control 2018, 92, 420-429. [CrossRef]

76. Regan, Á.; Raats, M.; Shan, L.C.; Wall, P.G.; McConnon, Á. Risk communication and social media during food safety crises: A study of stakeholders' opinions in Ireland. J. Risk Res. 2016, 19, 119-133. [CrossRef]

77. Arnot, C. Perspective-Building Consumer Trust in the Food System. Food Technol. 2011, 65, 132.

78. Anderson, W.A. The future relationship between the media, the food industry and the consumer. Br. Med. Bull. 2000, 56, 254-268. [CrossRef] [PubMed]

79. Tonkin, E.; Wilson, A.M.; Coveney, J.; Meyer, S.B.; Henderson, J.; McCullum, D.; Webb, T.; Ward, P.R. Consumers respond to a model for (re) building consumer trust in the food system. Food Control 2019, 101, 112-120. [CrossRef]

80. Jensen, K.K. BSE in the UK: Why the risk communication strategy failed. J. Agric. Environ. Ethics 2004, 17, 405-423. [CrossRef]

81. Jacob, C.J.; Lok, C.; Morley, K.; Powell, D.A. Government management of two media-facilitated crises involving dioxin contamination of food. Public Underst. Sci. 2011, 20, 261-269. [CrossRef]

82. Wilson, A.M.; Withall, E.; Coveney, J.; Meyer, S.B.; Henderson, J.; McCullum, D.; Webb, T.; Ward, P.R. A model for (re) building consumer trust in the food system. Health Promot. Int. 2017, 32, 988-1000. [CrossRef]

83. Falkheimer, J.; Heide, M. Trust and brand recovery campaigns in crisis: Findus Nordic and the horsemeat scandal. Int. J. Strateg. Commun. 2015, 9, 134-147. [CrossRef]

84. Hou, B.; Wu, L.; Chen, X.; Zhu, D.; Ying, R.; Tsai, F.S. Consumers' Willingness to Pay for Foods with Traceability Information: Ex-Ante Quality Assurance or Ex-Post Traceability? Sustainability 2019, 11, 1464. [CrossRef]

85. Jin, S.; Zhang, Y.; Xu, Y. Amount of information and the willingness of consumers to pay for food traceability in China. Food Control 2017, 77, 163-170. [CrossRef]

86. Liu, C.; Li, J.; Steele, W.; Fang, X. A study on Chinese consumer preferences for food traceability information using best-worst scaling. PLoS ONE 2018, 13, e0206793. [CrossRef]

87. Lu, J.; Wu, L.; Wang, S.; Xu, L. Consumer preference and demand for traceable food attributes. Br. Food J. 2016, 118, 2140-2156. [CrossRef]

88. Papadopoulos, A.; Sargeant, J.M.; Majowicz, S.E.; Sheldrick, B.; McKeen, C.; Wilson, J.; Dewey, C.E. Enhancing public trust in the food safety regulatory system. Health Policy 2012, 107, 98-103. [CrossRef]

89. Hoque, M.Z.; Alam, M. What determines the purchase intention of liquid milk during a food security crisis? The role of perceived trust, knowledge, and risk. Sustainability 2018, 10, 3722. [CrossRef]

90. Zhang, C.; Bai, J.; Wahl, T.I. Consumers' willingness to pay for traceable pork, milk, and cooking oil in Nanjing, China. Food Control 2012, 27, 21-28. [CrossRef] 
91. Yin, S.; Li, Y.; Xu, Y.; Chen, M.; Wang, Y. Consumer preference and willingness to pay for the traceability information attribute of infant milk formula: Evidence from a choice experiment in China. Br. Food J. 2017, 119, 1276-1288. [CrossRef]

92. Wu, L.; Gong, X.; Qin, S.; Chen, X.; Zhu, D.; Hu, W.; Li, Q. Consumer preferences for pork attributes related to traceability, information certification, and origin labeling: Based on China's Jiangsu Province. Agribusiness 2017, 33, 424-442. [CrossRef]

93. Kendall, H.; Naughton, P.; Kuznesof, S.; Raley, M.; Dean, M.; Clark, B.; Stolz, H.; Home, R.; Chan, M.Y.; Zhong, Q.; et al. Food fraud and the perceived integrity of European food imports into China. PLoS ONE 2018, 13, e0195817. [CrossRef]

94. My, N.H.D.; Demont, M.; Van Loo, E.J.; De Guia, A.; Rutsaert, P.; Tuan, T.H.; Verbeke, W. What is the value of sustainably-produced rice? Consumer evidence from experimental auctions in Vietnam. Food Policy 2018, 79, 283-296. [CrossRef]

95. Nawi, N.M.; Basri, H.N.; Kamarulzaman, N.H.; Shamsudin, M.N. Factors influencing consumers' preferences towards meat and meat products with traceability systems in Malaysia. Int. Food Res. J. 2018, S157-S164.

96. Zhang, A.; Mankad, A.; Ariyawardana, A. Establishing confidence in food safety: Is traceability a solution in consumers' eyes? J. Consum. Prot. Food Saf. 2020, 15, 99-107. [CrossRef]

97. Yuan, C.; Wang, S.; Yu, X. The impact of food traceability system on consumer perceived value and purchase intention in China. Ind. Manag. Data Syst. 2020, 120, 810-824. [CrossRef]

98. Henderson, J.; Coveney, J.; Ward, P.R.; Taylor, A.W. Farmers are the most trusted part of the Australian food chain: Results from a national survey of consumers. Aust. N. Z. J. Public Health 2011, 35, 319-324. [CrossRef] [PubMed]

99. Tonkin, E.; Henderson, J.; Meyer, S.B.; Coveney, J.; Ward, P.R.; McCullum, D.; Webb, T.; Wilson, A.M. Expectations and everyday opportunities for building trust in the food system. Br. Food J. 2020, 123, 702-719. [CrossRef]

100. Richards, C.; Lawrence, G.; Burch, D. Supermarkets and agro-industrial foods: The strategic manufacturing of consumer trust. Food Cult. Soc. 2011, 14, 29-47. [CrossRef]

101. Henderson, J.; Ward, P.; Coveney, J.; Meyer, S. Trust in the Australian food supply: Innocent until proven guilty. Health Risk Soc. 2012, 14, 257-272. [CrossRef]

102. Lupton, D.A. Lay discourses and beliefs related to food risks: An Australian perspective. Sociol. Health Illn. 2005, $27,448-467$. [CrossRef]

103. Carfora, V.; Cavallo, C.; Caso, D.; Giudice, T.D.; Devitiis, B.D.; Viscecchia, R.; Nardone, G.; Cicia, G. Explaining consumer purchase behavior for organic milk: Including trust and green self-identity within the theory of planned behavior. Food Qual. Prefer. 2019, 76, 1-9. [CrossRef]

104. Zhang, L.; Zhang, L.; Xu, Y.; Oosterveer, P.; Mol, A.P.J. Consumer trust in different food provisioning schemes: Evidence from Beijing, China. J. Clean. Prod. 2016, 134, 269-279. [CrossRef]

105. Li, S.; Sijtsema, S.J.; Kornelis, M.; Liu, Y.; Li, S. Consumer confidence in the safety of milk and infant milk formula in China. J. Dairy Sci. 2019, 102, 8807-8818. [CrossRef] [PubMed]

106. Zhu, B.; Kowatthanakul, S.; Satanasavapak, P. Generation Y consumer online repurchase intention in Bangkok: Based on Stimulus-Organism-Response (SOR) model. Int. J. Retail. Distrib. Manag. 2019. [CrossRef]

107. Frasquet, M.; Descals, A.M.; Ruiz-Molina, M.E. Understanding loyalty in multichannel retailing: The role of brand trust and brand attachment. Int. J. Retail. Distrib. Manag. 2017, 45, 608-625. [CrossRef]

108. Osman, H.; D'Acunto, D.; Johns, N. Home and away: Why do consumers shy away from reporting negative experiences in the peer-to-peer realms? Psychol. Mark. 2019, 36, 1162-1175. [CrossRef]

109. Ye, C.; Hofacker, C.F.; Peloza, J.; Allen, A. How online trust evolves over time: The role of social perception. Psychol. Mark. 2020, 37, 1539-1553. [CrossRef]

110. Zhllima, E.; Imami, D.; Canavari, M. Consumer perceptions of food safety risk: Evidence from a segmentation study in Albania. J. Integr. Agric. 2015, 14, 1142-1152. [CrossRef]

111. Liu, R.; Pieniak, Z.; Verbeke, W. Food-related hazards in China: Consumers' perceptions of risk and trust in information sources. Food Control 2014, 46, 291-298. [CrossRef]

112. Bauman, A.; Bachmann, R. Online consumer trust: Trends in research. J. Technol. Manag. Innov. 2017, 12, 68-79. [CrossRef]

113. Yue, L.; Liu, Y.; Wei, X. Influence of online product presentation on consumers' trust in organic food. Br. Food J. 2017. [CrossRef]

114. Chopdar, P.K.; Balakrishnan, J. Consumers response towards mobile commerce applications: SOR approach. Int. J. Inf. Manag. 2020, 53, 102106. [CrossRef]

115. Van Doorn, J.; Mende, M.; Noble, S.M.; Hulland, J.; Ostrom, A.L.; Grewal, D.; Petersen, J.A. Domo arigato Mr. Roboto: Emergence of automated social presence in organizational frontlines and customers' service experiences. J. Serv. Res. 2017, 20, 43-58. [CrossRef]

116. Lu, B.; Fan, W.; Zhou, M. Social presence, trust, and social commerce purchase intention: An empirical research. Comput. Hum. Behav. 2016, 56, 225-237. [CrossRef]

117. Lin, X.; Wang, X.; Hajli, N. Building e-commerce satisfaction and boosting sales: The role of social commerce trust and its antecedents. Int. J. Electron. Commer. 2019, 23, 328-363. [CrossRef]

118. Dong, B.; Li, M.; Sivakumar, K. Online review characteristics and trust: A cross-country examination. Decis. Sci. 2019, 50, 537-566. [CrossRef]

119. Chen, M.F. Consumer trust in food safety-A multidisciplinary approach and empirical evidence from Taiwan. Risk Anal. Int. J. 2008, 28, 1553-1569. [CrossRef] 
120. Buddle, E.A.; Bray, H.J. How farm animal welfare issues are framed in the Australian media. J. Agric. Environ. Ethics 2019, 32, 357-376. [CrossRef]

121. Bray, H.J.; Ankeny, R.A. Happy chickens lay tastier eggs: Motivations for buying free-range eggs in Australia. Anthrozoös 2017, 30, 213-226. [CrossRef] 